INTERNATIONAL JOURNAL OF PLANT PROTECTION VOLUME 9 | ISSUE 1 | APRIL, 2016 | 26-29
- e ISSN-0976-6855 | Visit us : www.researchjournal.co.in

DOI : 10.15740/HAS/IJPP/9.1/26-29

\title{
Effect of tomatine on Termitomyces fungus in termitaria of subterranean termites Odontotermes wallonensis Wasmann
}

\author{
R. NISHA* AND D.S. RAJAVEL ${ }^{1}$
}

Department of Crop Protection, Imayam Institute of Agriculture and Technology, Kannanur, Thuraiyur, TRICHY (T.N.) INDIA

${ }^{1}$ Department of Agricultural Entomology, Agricultural College and Research Institute, Killikulam, TUTICORIN (T.N.) INDIA

\section{ARITCLE INFO}

Received : 30.12 .2015

Revised : 03.02 .2016

Accepted : 17.02 .2016

KEY WORDS :

Tomatine, Subterranean Termites,

Termitaria, Termitomyces

*Corresponding author:

Email: nisharengadoss@gmail.com

\section{ABSTRACT}

Tomatine is a glycoalkaloid found in the stems and leaves of tomato plants, which has fungicidal properties. This laboratory studies were carried out to find out the efficacy of tomatine on the Termitomyces fungus found in the termitaria of $O$. wallonensis, it was applied through Difco media for fungal growth. The overall period of observations (15 days) revealed that tomatine $1000 \mathrm{ppm}$ effectively reduced the mean diameter growth of fungus $(1.41 \mathrm{~cm})$ followed by tomatine $900 \mathrm{ppm}(1.52 \mathrm{~cm})$. The fungal growth of fungus in the standard check carbendazim $500 \mathrm{ppm}$ was $1.32 \mathrm{~cm}$ whereas it was $8.17 \mathrm{~cm}$ in untreated check. The highest suppression of fungus was noticed in carbendazim 500 ppm $(84.59 \%)$ which was on par with tomatine $1000 \mathrm{ppm}$ (83.44\%). Tomatine $900 \mathrm{ppm}$ was also suppressed the fungus effectively at 82.08 per cent. The least mean per cent suppression $(68.37 \%)$ was noticed in the lower concentration of tomatine $600 \mathrm{ppm}$. The per cent suppression of fungal growth was decreased from $5^{\text {th }}$ day to $15^{\text {th }}$ day of observation. This study was supported by many earlier contributions. Finally the result was concluded that tomatine could be used as a termiticide to control fungus growing termites.

How to view point the article : Nisha, R. and Rajavel, D.S. (2016). Effect of tomatine on Termitomyces fungus in termitaria of subterranean termites Odontotermes wallonensis Wasmann. Internat. J. Plant Protec., 9(1) : 26-29. 